J. Lake Sci. (湖泊科学), 2015, 27(3): 412-420

http: //www. jlakes.org. E-mail : jlakes@niglas.ac.cn

(C) 2015 by Journal of Lake Sciences

\title{
珠江流域西江支流贺江浮游藻类群落特征及水质分析”
}

\author{
苟 婷 ${ }^{1,2}$, 许振成 ${ }^{1,2}$, 李 杰 $^{2}$, 马千里 ${ }^{1}$, 王 丽 $^{1}$, 赵学敏 ${ }^{1 * *}$, 梁荣昌 ${ }^{1}$, 郭俊成 ${ }^{1}$ \\ ( 1 : 环境保护部华南环境科学研究所, 广州 510655) \\ ( 2 : 兰州交通大学环境与市政工程学院, 兰州 730070)
}

摘 要: 为了解珠江流域西江支流贺江浮游藻类的分布并评价其水质情况, 于 2013 年丰水期和枯水期对贺江的浮游藻 类群落结构进行调查和分析, 结果表明: 调查期间共检出浮游藻类 7 门 130 种, 其中丰水期 7 门 63 种,枯水期 5 门 103 种, 浮游藻类群落组成以绿藻门、硅藻门和蓝藻门为主, 丰水期绿藻门居多, 硅藻门次之, 藻细胞丰度平均值为 $2.13 \times$ $10^{6} \mathrm{cells} / \mathrm{L}$; 枯水期硅藻门最多, 藻细胞丰度平均值为 $3.71 \times 10^{6} \mathrm{cells} / \mathrm{L}$; 优势种主要有水华微囊藻、卷曲鱼腥藻、小颤藻、 啮蚀隐藻、短小舟形藻、变异直链藻、颗粒直链藻、四尾栅藻、集星藻、小球衣藻和小球藻. RDA 分析表明, 影响贺江浮游藻 类群落分布的主要环境因子是氮、磷营养盐, 综合营养状态指数显示贺江处于中营养水平.

关键词: 贺江; 浮游藻类; 群落结构; 环境因子; 综合营养状态指数

\section{Phytoplankton community structure and water quality assessment of Hejiang River, a branch of Xijiang River, Pearl River drainage basin}

GOU Ting ${ }^{1,2}$, XU Zhencheng ${ }^{1,2}$, LI Jie ${ }^{2}$, MA Qianli ${ }^{1}$, WANG Li $^{1}$, ZHAO Xuemin ${ }^{1}$, LIANG Rongchang ${ }^{1} \&$ GUO Juncheng ${ }^{1}$

(1: South China Institute of Environmental Sciences, Ministry of Environmental Protection, Guangzhou 510655, P. R. China)

(2: College of Environmental and Municipal Engineering, Lanzhou Jiaotong University, Lanzhou 730070, P. R. China)

Abstract: To study the distribution of phytoplankton and evaluate water quality of Hejiang River, a branch of Xijiang River, Pearl River drainage basin, the community structure of phytoplankton was investigated and analyzed in wet and dry seasons in 2013 . The results showed that a total of 130 species belonging to seven phyla of phytoplankton was identified. Including 63 species of seven phyla in wet season and 103 species of five phyla in dry season, phytoplankton community structure in Hejiang River was represented by Chlorophyta, Bacillariophyta and Cyanophyta. Chlorophyta was dominant in wet season, followed by Bacillariophyta. The mean value of phytoplankton density was $2.13 \times 10^{6}$ cells/L. Bacillariophyta dominated the phytoplankton in dry season, and the mean value of phytoplankton density was $3.71 \times 10^{6}$ cells/L. The dominant species were Microcystis flos-aquae, Anabaena circinalis, Oscillatoria tenuis, Cryptomonas erosa, Navicula exigua, Melosira varians, Melosira granulata, Scenedesmus quadricauda, Actinastrum hantzschii, Chlamydomonas microsphaera and Chlorella valgaris. Based on RDA analysis, nitrogen and phosphorus were important environmental factors that affected the distribution of phytoplankton in Hejiang River. The river was classified as mesotrophic according to comprehensive trophic state index.

Keywords: Hejiang River; phytoplankton; community structure; environmental factors; comprehensive trophic level index

水生态系统中浮游藻类的群落结构、种群数量随水环境的变化而改变, 并且藻类能对水环境的改变做 出灵敏而迅速的响应 ${ }^{[1-3]}$. 河流生态系统中的浮游藻类生活周期短, 对水环境变化敏感, 藻类特征的变化可 被看成是对水质变化的一个良好的指示, 同时也是评价河流水体质量的一项重要标准 ${ }^{[4-5]}$. 河流浮游藻类的

* 国家自然科学基金项目(41401115)、国家水体污染控制与治理科技重大专项(2014ZX07206-005-04)、贺江后评估项目(PMZX024-201402-023) 和鹤地水库蓝藻水华监控与应急处置技术项目 (PM-ZX022-201409-014) 联合资助. 2014-05 - 22 收稿; 2014-10-16 收修改稿. 苟婷(1988 ), 女, 硕士研究生;E-mail :gouting0212@ 126. com.

** 通信作者; E-mail:zhaoxuemin@ scies. org. 
生态学特征除了受到河流自然生境的影响,还会更多地受到人类活动的影响 ${ }^{[6-7]}$. 水利工程建设、拦坝建库、 排污等人类活动的干扰, 导致河流浮游藻类的生态学特征具有显著的空间异质性和多样性 ${ }^{[8]}$. 如王爱爱 等 ${ }^{[9]}$ 研究的汾河中下游浮游藻类的种类数和比例存在一定的空间分布差异,这与部分样点周边铁厂、洗煤 厂等小企业污水的直接排放关系密切; 李芳芳等 ${ }^{[10]}$ 对大辽河水系夏季浮游植物群落结构特征的研究表明, 由于上游河流型水库大伙房水库的建成, 导致该段浮游藻类生态状况发生变化,优势门类从硅藻逐渐演变 为绿藻.

贺江 ( $23^{\circ} 20^{\prime} \sim 25^{\circ} 08^{\prime} \mathrm{N}, 111^{\circ} 08^{\prime} \sim 112^{\circ} 11^{\prime} \mathrm{E}$ ) 是珠江流域西江水系的一级支流, 其上游富川江发源于富 川瑶族自治县麦岭乡的茗山, 向南流经富川县、钟山县、贺州市、广东省封开县,于封开县江口镇注人西江干 流, 全长 $352 \mathrm{~km}$, 集水面积 $11536 \mathrm{~km}^{2}$, 多年平均流量 $193.3 \mathrm{~m}^{3} / \mathrm{s}$, 整个流域地处北回归线以北, 属亚热带季 风气候, 年平均气温 $20^{\circ} \mathrm{C}$ 左右, 流域内修筑了包括龟石水库 (贺江上游)、合面狮水库 (贺江中游)、江口电站 (贺江下游)等多座大中型水库. 贺江是贺州市的主要饮用水源, 其水质安全对贺州市社会稳定和经济发展 具有十分重要的意义. 因此本研究全面调查贺江水生态及水质状况, 从水体理化指标、浮游藻类种类组成、 群落结构变化等方面人手, 探讨影响贺江浮游藻类群落分布的环境因子, 并综合评价贺江水质情况, 从而为 贺江的水环境保护提供科学依据.

\section{1 材料与方法}

\section{1 采样点设置}

在贺江上游至下游共设置 9 个采样点 ( 图 1 ), 其中 $1^{\#}$ 龟石水库位于贺江上游, $2^{\#}$ 位于马尾

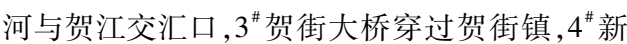
忠码头位于合面狮水库库尾, $5^{\#}$ 位于合面狮水 库坝首, $6^{\#}$ 位于扶隆码头, $7^{\#}$ 位于白垢镇, $8^{\#}$ 位于 江口电站 (库区), $9^{\#}$ 位于贺江与西江交汇口下 游西江干流上.

\section{2 样品采集与分析}

1.2 .1 水质分析 于 2013 年丰水期 (7 月) 和枯 水期(11月)对贺江 9 个点位进行调查分析. 现 场测定 $\mathrm{pH}$ 、水温 $(\mathrm{T})$ 、溶解氧 ( DO ) 、电导率 (Cond)、透明度 $(\mathrm{SD})$, 采集表层水样 $1 \mathrm{~L}$ 带回 实验室测定叶绿素 $a($ Chl. a) 、总氮 (TN)、氨氮 $\left(\mathrm{NH}_{3}-\mathrm{N}\right)$ 、硝态氮 $\left(\mathrm{NO}_{3}^{-}-\mathrm{N}\right)$ 、总磷 $(\mathrm{TP})$ 以及高 锰酸盐指数 $\left(\mathrm{COD}_{\mathrm{Mn}}\right)$, 测定方法均参考《水和废 水监测方法 (第四版) $\rangle^{[11]}$.

1.2 .2 浮游藻类分析 浮游藻类定性样品用 $25^{\#}$ 浮游生物网在表层水中呈“ $\infty$ ” 形来回捞取, $4 \%$ 的福尔马林溶液固定, 显微镜下进行种类鉴 定; 浮游藻类定量样品用采水器采集表层 (水下 $0.5 \mathrm{~m}$ ) 水样 $1 \mathrm{~L}$, 加人 $10 \mathrm{ml}$ 鲁哥试剂固定, 样 品经沉淀、浓缩、定容后, 采用目镜视野计数法 进行藻类细胞计数与鉴定 ${ }^{[12]}$.

1.2.3 评价方法 综合营养状态指数 $(T L I)$ 法, 使用 Carlson 方法评价 ${ }^{[13]}$,公式如下:

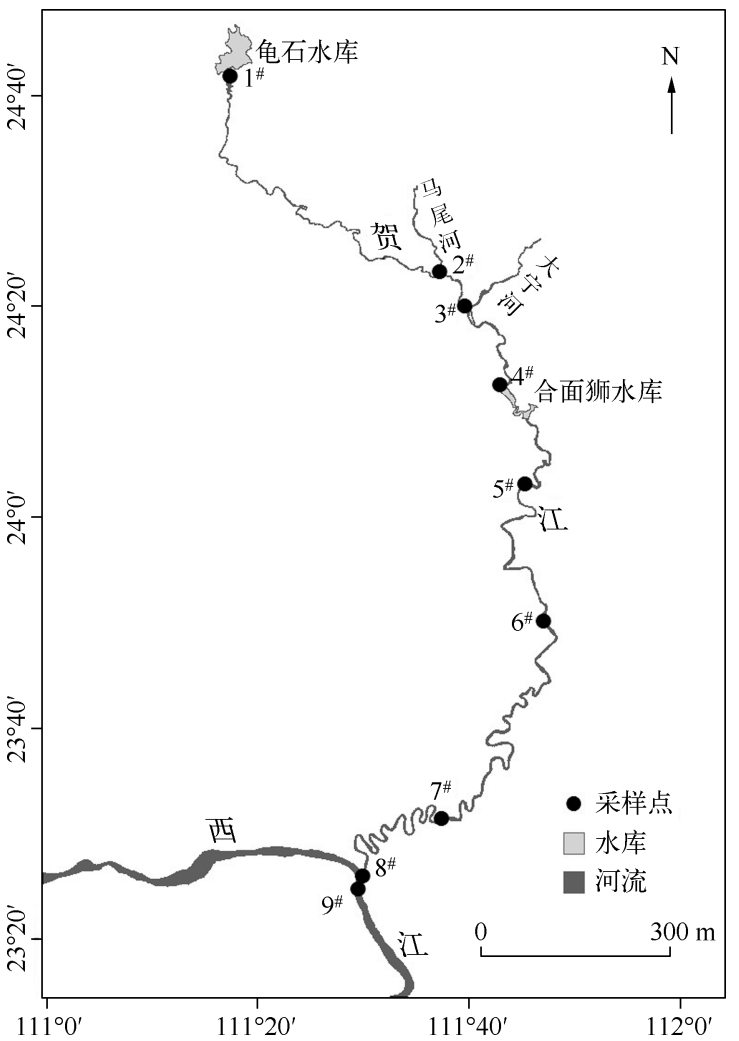

图 1 贺江采样点位分布

Fig. 1 Location of sampling sites in Hejiang River

$$
T L I(\Sigma)=\sum_{j=1}^{m} W_{j} \cdot \operatorname{TLI}(j)
$$


式中, $T L I(\Sigma)$ 表示综合营养状态指数, $T L I(j)$ 代表第 $j$ 种参数的营养状态指数, $W_{j}$ 为第 $j$ 种参数的营养状 态指数的相关权重. 浮游藻类优势度指数 ${ }^{[14]}(Y)$ 的计算公式为:

$$
Y=f_{i}\left(n_{i} / N\right)
$$

式中, $n_{i} / N$ 为第 $i$ 个物种个体数与样品中总个体数的比值, $n_{i}$ 为样品中第 $i$ 种浮游藻类的个体数, $N$ 为样品 中浮游藻类总个体数, $f_{i}$ 为第 $i$ 种浮游藻类在各样点出现的频度, 当 $Y \geqslant 0.02$ 时的物种为优势种.

\section{3 数据处理}

采用 Canoco for Windows 4.5 软件对物种数据和环境数据进行排序分析, 物种经过篮选, 满足在各样点 出现的频度 $>12.5 \%$ 和至少在一个样点的相对丰度 $>1 \%^{[15-16]}$, 物种矩阵经过 $\lg (x+1)$ 转换, 环境因子数据 除 $\mathrm{pH}$ 外全部进行 $\lg (x+1)$ 转换 ${ }^{[17]}$, 基本图形绘制在 Origin 8.5 中完成.

\section{2 结果与分析}

\section{1 浮游藻类群落特征}

2.1 .1 浮游藻类群落组成 调查期间, 贺江共检出浮游藻类 7 门 130 种, 其中丰水期检出 7 门 63 种, 枯水期检 出 5 门 103 种. 丰水期和枯水期浮游藻类种类均主要由绿藻门、硅藻门和蓝澡门组成, 所占比例达 $92.07 \%$ $97.09 \%$, 甲藻门、金藻门、隐藻门和裸藻门种类较少, 仅占 $2.91 \%$ 7.94\% (表 1).

表 1 贺江各门浮游藻类种类数及所占比例

Tab. 1 Species number and proportion of each phytoplankton phylum in Hejiang River

\begin{tabular}{ccccccccc}
\hline 时期 & 种类组成 & 硅藻门 & 绿藻门 & 蓝藻门 & 隐藻门 & 甲藻门 & 金藻门 & 裸藻门 \\
\hline 丰水期 & 种类数 & 16 & 37 & 5 & 1 & 2 & 1 & 1 \\
& 比例 $/ \%$ & 25.40 & 58.73 & 7.94 & 1.59 & 3.17 & 1.59 & 1.59 \\
\multirow{2}{*}{ 枯水期 } & 种类数 & 43 & 42 & 15 & 1 & 2 & - & - \\
& 比例 $/ \%$ & 41.75 & 40.78 & 14.56 & 0.97 & 1.94 & - & - \\
\hline
\end{tabular}

2.1 .2 浮游藻类优势种及其优势度 根据公式 $(2)$ 及 $Y \geqslant 0.02$ 的标准, 分别计算丰水期和枯水期浮游藻类 的优势度, 调查期间, 贺江共有浮游藻类优势种 11 种, 包括蓝藻门 3 种: 水华微囊藻 (Microcystis flos-aquae)、 卷曲鱼腥藻 (Anabaena circinalis) 、小颤藻 (Oscillatoria tenuis), 隐藻门 1 种: 啮蚀隐藻 (Cryptomonas erosa), 硅 藻门 3 种: 短小舟形藻 (Navicula exigua) 、变异直链藻 (Melosira varians)、颗粒直链藻 (Melosira granulata), 绿 藻门 4 种: 四尾栅藻 (Scenedesmus quadricauda)、集星藻 (Actinastrum hantzschii) 、小球衣藻 (Chlamydomonas microsphaera) 、小球藻 (Chlorella valgaris). 丰水期有优势种 10 种, 出现频度均 $\geqslant 30 \%$, 蓝藻门的水华微囊藻 为第一优势种, 出现频度为 $89 \%$, 优势度为 0.30 ; 其次为绿藻门的四尾栅藻, 出现频度为 $56 \%$, 优势度为 0.06 ; 枯水期优势种 4 种, 与丰水期相比, 绿藻门藻类不再是优势种, 水华微囊藻出现频度也降低为 $22 \%$, 优 势度则降为 0.02 , 卷曲鱼腥藻出现频度不变, 为 $78 \%$, 优势度由丰水期的 0.03 升高为 0.42 , 成为枯水期的 第一优势种,隐藻门的啮蚀隐藻为第二优势种.

2.1 .3 浮游藻类细胞丰度 贺江丰水期浮游藻类总细胞丰度介于 $5.71 \times 10^{5} \sim 1.16 \times 10^{7} \mathrm{cells} / \mathrm{L}$ 之间, 平均 值为 $2.13 \times 10^{6} \mathrm{cells} / \mathrm{L}$; 枯水期浮游藻类细胞总丰度介于 $3.37 \times 10^{5} \sim 2.49 \times 10^{7} \mathrm{cells} / \mathrm{L}$ 之间, 平均值为 $3.71 \times$ $10^{6} \mathrm{cells} / \mathrm{L}$; 丰水期和枯水期均以龟石水库样点 $\left(1^{\#}\right)$ 浮游藻类细胞总丰度最高, 且枯水期 $\left(2.49 \times 10^{7} \mathrm{cells} / \mathrm{L}\right)$ 高于丰水期 $\left(1.16 \times 10^{7} \mathrm{cells} / \mathrm{L}\right)$; 白垢镇样点 $\left(7^{\#}\right)$ 浮游藻类细胞总丰度枯水期比丰水期显著升高, 由 $0.79 \times$ $10^{6} \mathrm{cells} / \mathrm{L}$ 升高到 $2.71 \times 10^{6} \mathrm{cells} / \mathrm{L}$, 而新忠码头样点 $\left(4^{\#}\right)$ 浮游藻类细胞总丰度明显降低, 由 $1.88 \times 10^{6} \mathrm{cells} / \mathrm{L}$ 降低到 $0.34 \times 10^{6} \mathrm{cells} / \mathrm{L}$, 其它样点浮游藻类丰度变化不大 (图 2 ).

\section{2 水体理化参数}

调查期间, 贺江水体 TN、TP 浓度变幅分别为 $1.22 \sim 3.06 \mathrm{mg} / \mathrm{L}$ 和 $0.02 \sim 0.20 \mathrm{mg} / \mathrm{L}, \mathrm{NH}_{3}-\mathrm{N} 、 \mathrm{NO}_{3}^{-}-\mathrm{N}$ 浓度 范围分别为 $0.03 \sim 0.75 \mathrm{mg} / \mathrm{L}$ 和 $0.81 \sim 1.92 \mathrm{mg} / \mathrm{L}$, 水温在 $17.6 \sim 31.4^{\circ} \mathrm{C}$ 间波动, DO 为 $5.44 \sim 10.64 \mathrm{mg} / \mathrm{L}$ (表 2). 单因素方差 (one-way ANOVA) 分析结果显示, 除 $\mathrm{SD} 、 \mathrm{NO}_{3}^{-}-\mathrm{N} 、 \mathrm{TN}$ 和 Chl. a 外, 各个环境因子在丰水 


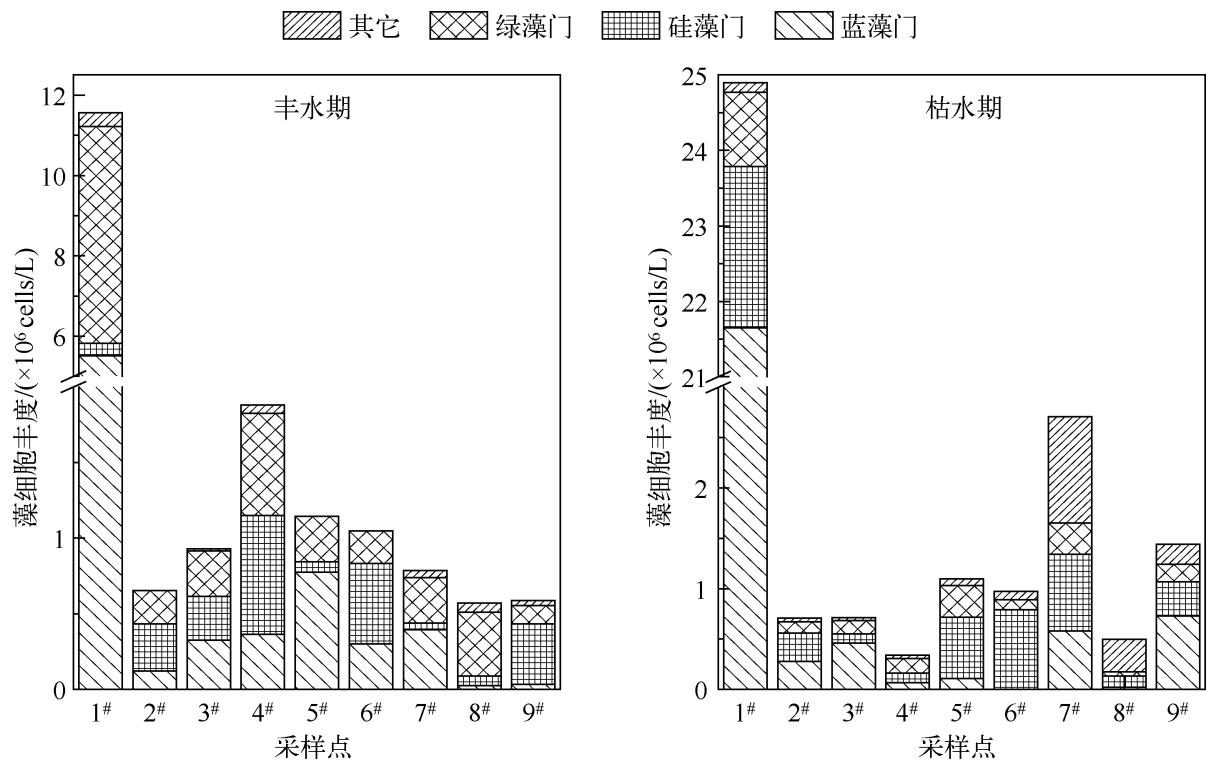

图 2 贺江各采样点浮游藻类细胞丰度组成

Fig. 2 Phytoplankton cell abundance of each sampling site in Hejiang River

期和枯水期间差异极显著 $(P<0.01), \mathrm{DO} 、 \mathrm{NH}_{3}-\mathrm{N}$ 和 $\mathrm{TP}$ 浓度在丰水期显著高于枯水期, $\mathrm{pH}$ 和 Cond 在丰水 期显著低于枯水期.

表 2 贺江水体主要理化参数

Tab. 2 Physicochemical parameters of water in Hejiang River

\begin{tabular}{|c|c|c|c|c|c|c|c|c|}
\hline \multirow{2}{*}{ 理化参数 } & \multicolumn{4}{|c|}{ 丰水期 } & \multicolumn{4}{|c|}{ 枯水期 } \\
\hline & 平均值 & 标准差 & 最大值 & 最小值 & 平均值 & 标准差 & 最大值 & 最小值 \\
\hline $\mathrm{DO} /(\mathrm{mg} / \mathrm{L})$ & 8.29 & 1.04 & 10.64 & 6.91 & 6.81 & 0.86 & 8.42 & 5.44 \\
\hline $\mathrm{T} /{ }^{\circ} \mathrm{C}$ & 29.5 & 1.17 & 31.4 & 27.8 & 20.0 & 1.29 & 21.4 & 17.6 \\
\hline $\mathrm{pH}$ & 7.36 & 0.27 & 7.75 & 6.85 & 8.51 & 1.08 & 10.04 & 7.25 \\
\hline Cond $/(\mu \mathrm{S} / \mathrm{cm})$ & 158.0 & 44.70 & 246.9 & 99.4 & 194.4 & 43.04 & 263.4 & 141.7 \\
\hline $\mathrm{NO}_{3}^{-}-\mathrm{N} /(\mathrm{mg} / \mathrm{L})$ & 1.34 & 0.32 & 1.92 & 0.81 & 1.35 & 0.36 & 1.84 & 0.87 \\
\hline $\mathrm{NH}_{3}-\mathrm{N} /(\mathrm{mg} / \mathrm{L})$ & 0.31 & 0.24 & 0.75 & 0.07 & 0.19 & 0.19 & 0.54 & 0.03 \\
\hline $\mathrm{TN} /(\mathrm{mg} / \mathrm{L})$ & 1.80 & 0.55 & 3.06 & 1.26 & 1.77 & 0.53 & 2.75 & 1.22 \\
\hline $\mathrm{TP} /(\mathrm{mg} / \mathrm{L})$ & 0.10 & 0.06 & 0.20 & 0.02 & 0.07 & 0.04 & 0.13 & 0.02 \\
\hline $\mathrm{COD}_{\mathrm{Mn}} /(\mathrm{mg} / \mathrm{L})$ & 2.11 & 0.46 & 3.10 & 1.67 & 1.96 & 0.41 & 2.70 & 1.30 \\
\hline Chl. a/ $(\mu \mathrm{g} / \mathrm{L})$ & 2.69 & 1.53 & 5.86 & 1.16 & 3.17 & 5.13 & 16.70 & 0.58 \\
\hline
\end{tabular}

\section{3 贺江营养状态评价}

贺江水环境 $T L I$ 如图 3 所示, 除马尾河与贺江交汇口样点 $\left(2^{\#}\right)$ 丰水期 $T L I$ 为 52.1 外, 其他各样点均在 $30 \sim 50$ 之间, 水质整体处于中营养水平. 但丰水期、枯水期营养状态有所差异, 除个别样点 $\left(1^{\# 、} 、 8^{\#}\right)$ 外, 丰水 期 $T L I$ 值均高于枯水期, 说明贺江水体丰水期营养程度较严重. TN 是导致贺江综合营养状态指数偏高的主 要原因, $2^{\#}$ 样点污染严重可能与附近居民生活污水排放和支流水质的营养状况有关.

\section{4 浮游藻类群落与环境因子的关系}

对经过篮选的 52 种浮游藻类 (代码见表 3 , 其中丰水期 30 种, 枯水期 37 种) 与 7 个环境因子进行排序 分析. DCA 分析表明,丰水期和枯水期 4 个轴中梯度最大值分别为 1.918 和 2.199 ,均小于 3 , 说明数据适用 


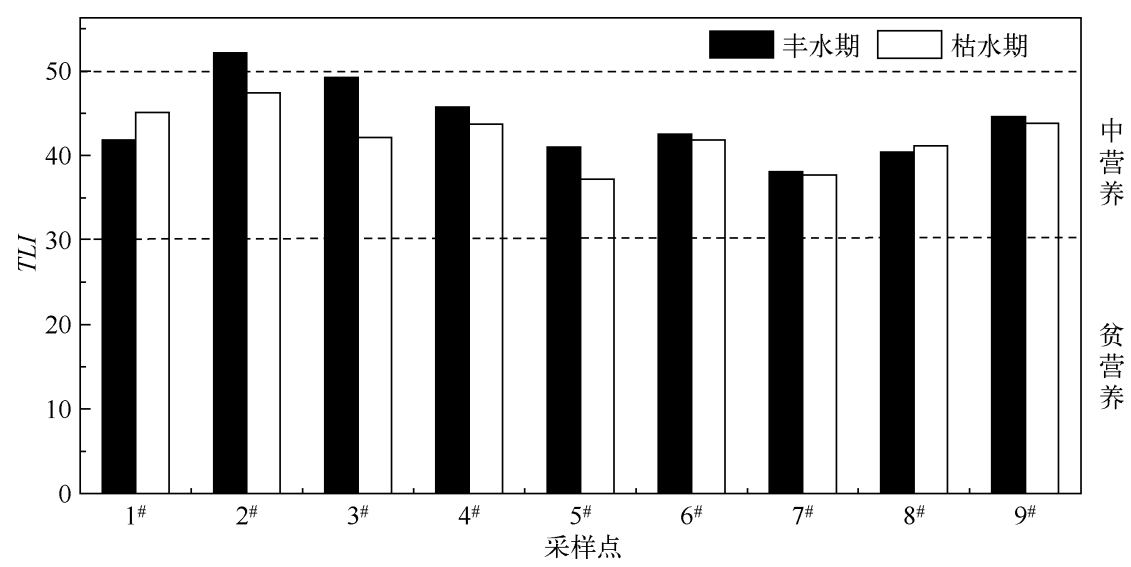

图 3 贺江各样点综合营养状态指数

Fig. 3 The comprehensive trophic state index of each sampling site in Hejiang River

于 $\mathrm{RDA}$ 分析 (表 4). 丰水期、枯水期 4 个环境因子轴与物种轴之间的相关系数均接近 1.000 , 说明排序图能 很好地反映藻类与环境因子之间的关系 ${ }^{[18]}$, 丰水期、枯水期共累计解释了浮游藻类物种和环境关系的 $83.5 \% 、 84.3 \%$. RDA 排序结果 (图 4) 表明, 丰水期影响贺江浮游藻类分布的主要环境因子是 $\mathrm{TP} 、 \mathrm{NH}_{3}-\mathrm{N}$ 和 $\mathrm{TN}$; 枯水期影响贺江浮游藻类分布的主要环境因子是 DO、TN. 因此, 氮、磷营养盐是影响贺江浮游藻类群落 分布最主要的环境因子.

\section{3 讨论}

\section{1 贺江浮游藻类群落特征}

河流是人类开发活动较多的区域, 据世界自然基金会 (WWF) 与世界资源研究所的报告显示: 世界上最 长的 227 条河流中, 有 $60 \%$ 以上被水坝、运河和引水工程所阻断. 河流建坝形成水库后, 从本质上改变了河 流的水动力条件, 河流生境发生变化, 生境的差异导致浮游藻类群落分布不同 ${ }^{[19]}$. 贺江由于上游龟石水库、 中游合面狮水库、下游江口电站的建成, 使其部分河段由河相类型转变为湖库相类型. 与其它河流、水库的 研究结果类似 ${ }^{[20-22]}$, 贺江河流段浮游藻类以硅藻门为主, 其中舟形藻、直链藻、菱形藻、尖针杆藻、羽纹藻、桥 弯藻和梅尼小环藻占绝对优势, 而龟石水库 $\left(1^{\#}\right)$ 、合面狮水库 $\left(5^{\#}\right)$ 、江口电站 $\left(8^{\#}\right)$ 的浮游藻类以绿藻门居 多, 更接近水库浮游藻类的分布特征, 其中栅藻、卵囊藻、四角藻、衣藻、小球藻和月牙藻所占比例较大. 龟石 水库的藻细胞丰度高达 $1.16 \times 10^{7} \sim 2.49 \times 10^{7} \mathrm{cells} / \mathrm{L}$, 主要是由于龟石水库地处低山丘陵, 水库蓄水后在水 库周边的小范围山地形成天然港湾, 库区周边的污染来源多且直接排人水体, 水体氮、磷营养盐丰富, 并且 流速极慢, 长年适宜的条件导致藻类大量繁殖. 研究认为, 中营养型水体以甲藻门、隐藻门和硅藻门占优势, 而富营养型水体以蓝藻门、绿藻门占优势 ${ }^{[23]}$, 贺江藻类组成以硅藻门和绿藻门为主, 属于中-富营养型水体, 与综合营养状态指数法评价结果一致. 贺江浮游藻类群落的组成与相近水体东江干流 ${ }^{[24]}$ 和西江下游的珠三 角河网水域 ${ }^{[25]}$ 的群落组成相似, 但在不同时期浮游藻类的组成比例、优势种和藻细胞丰度差异明显. 贺江浮 游藻类枯水期硅藻门种类所占比例显著提高, 绿藻门种类比例有所下降 (表 1), 并且绿藻门种类不再是枯水 期的优势种, 这说明贺江水体丰水期比枯水期污染严重, 丰水期水质较差; 浮游藻类的总细胞丰度枯水期略 高于丰水期, 这与表征藻类生物量的参数叶绿素 $\mathrm{a}$ 显示的结果一致, 但各样点藻细胞丰度分布不均匀 (图 2), 这与各江段水体营养条件的差异有关.

\section{2 贺江浮游藻类群落分布与环境因子的关系}

浮游藻类群落结构在不同水体具有不同的特征, 其演替规律是众多环境因子在时间和空间上相互影响 的结果 ${ }^{[26-27]}$. 研究表明, 水温是影响浮游藻类分布的重要环境因子 ${ }^{[28]}$, 水温为 $20^{\circ} \mathrm{C}$ 左右时以硅藻为主, $30^{\circ} \mathrm{C}$ 以绿藻为主, $40^{\circ} \mathrm{C}$ 以蓝藻为主. 贺江丰水期和枯水期平均水温分别为 29.5 和 $20.0^{\circ} \mathrm{C}$, 浮游藻类的变化规律 
是由丰水期的绿藻向枯水期的硅藻转变; 水体 $\mathrm{pH}$ 值与藻类生长密切相关 ${ }^{[29]}$, 不同藻类生长都有其适合的 $\mathrm{pH}$ 范围 ${ }^{[29]}$, 本研究中丰水期 $\mathrm{pH}$ 与绿藻相关性较高, 枯水期与蓝藻相关性较高; RDA 分析显示, DO 也是影 响贺江浮游藻类分布的重要环境因子, 浮游藻类在大量生长时由于光合作用对水体有较强的富氧作用,而 在藻类大量死亡时则需要消耗大量 $\mathrm{DO}^{[30]}$.

\section{表 3 贺江 RDA 分析浮游藻类代码}

Tab. 3 Phytoplankton codes for RDA in Hejiang River

\begin{tabular}{|c|c|c|c|c|c|}
\hline \multicolumn{2}{|c|}{ 代码 } & \multirow{2}{*}{ 种名 } & \multicolumn{2}{|c|}{ 代码 } & \multirow{2}{*}{ 种名 } \\
\hline 丰水期 & 枯水期 & & 丰水期 & 枯水期 & \\
\hline $\mathrm{A} 1$ & A1 & 微囊藻 Microcystis sp. & D19 & D19 & 异极藻 Gomphonema sp. \\
\hline $\mathrm{A} 2$ & $\mathrm{~A} 2$ & 颤藻 Oscillatoria sp. & $\mathrm{D} 20$ & & 布纹藻 Gyrosigma sp. \\
\hline \multirow[t]{2}{*}{$\mathrm{A} 3$} & A3 & 伪鱼腥藻 Pseudanabaena sp. & D21 & & 脆杆藻 Fragilaria sp. \\
\hline & A4 & 鱼腥藻 Anabaena sp. & $\mathrm{D} 22$ & & 楔形藻 Licmophora sp. \\
\hline \multirow[t]{2}{*}{ A5 } & & 色球藻 Chroococcus sp. & E1 & & 绿球藻 Chlorococcum sp. \\
\hline & A6 & 粘球藻 Gloeocapsa sp. & E2 & E2 & 实球藻 Pandorina morum \\
\hline \multirow[t]{2}{*}{ B1 } & B1 & 隐藻 Cryptomonas sp. & E3 & E3 & 栅藻 Scenedesmus sp. \\
\hline & C1 & 多甲藻 Peridinium sp. & $\mathrm{E} 4$ & & 四尾栅藻 Scenedesmus quadricauda \\
\hline \multirow[t]{7}{*}{ D1 } & & 直链藻 Melosira sp. & & E5 & 成对栅藻 Scenedesmus bijuga \\
\hline & $\mathrm{D} 2$ & 颗粒直链藻 Melosira granulata & E6 & E6 & 十字藻 Crucigenia apiculata \\
\hline & D3 & $\begin{array}{l}\text { 螺旋颗粒直链藻 Melosira granulata var. } \\
\text { angustissima } f \text {. spiralis }\end{array}$ & E7 & & 集星藻 Actinastrum hantzschii \\
\hline & D4 & 菱形藻 Nitzschia sp. & E8 & E8 & 单角盘星藻 Pediastrum simplex \\
\hline & D5 & 斜纹长簏藻 Neidium kozlowi & & E9 & 四角盘星藻 Pediastrum tetras \\
\hline & D6 & 双菱藻 Surirella sp. & & E10 & 二角盘星藻 Pediastrum duplex \\
\hline & D7 & 卵形藻 Cocooneis sp. & E11 & & 衣藻 Chlamydomonas sp. \\
\hline \multirow[t]{3}{*}{ D8 } & D8 & 针杆藻 Synedra sp. & E12 & E12 & 卵囊藻 Oocystis sp. \\
\hline & D9 & 尖针杆藻 Synedra acus & E13 & E13 & 新月藻 Closterium sp. \\
\hline & D10 & 肘状针杆藻 Synedra ulna & E14 & & 鼓藻 Cosmarium sp. \\
\hline \multirow[t]{2}{*}{ D11 } & D11 & 舟形藻 Navicula sp. & E15 & & 小球藻 Chlorella sp. \\
\hline & D12 & 四棘藻 Treubaria triappen-diculata & E16 & & 月牙藻 Selenastrum dibraianum \\
\hline D13 & D13 & 桥弯藻 Cymbella sp. & E17 & & 纤维藻 Ankistrodesmus sp. \\
\hline \multirow[t]{5}{*}{ D14 } & D14 & 小环藻 Cyclotella operculata & E18 & & 小椿藻 Characium sp. \\
\hline & D15 & 冠盘藻 Stephanodiscus hantzschii & E19 & & 棘球藻 Echinosphaerella limnetica \\
\hline & D16 & 星形冠盘藻 Stephanodiscus astraca & & E20 & 膨胀四角藻 Tetraëdron tumidulum \\
\hline & D17 & 梅尼小环藻 Cyclotella meneghiniana & & E21 & 镰形纤维藻 Ankistrodesmus falcatus \\
\hline & D18 & 双头辐节藻 Stauroneis anceps & & E22 & 空球藻 Eudorina elegans \\
\hline
\end{tabular}

表 4 贺江浮游藻类与环境因子的 RDA 分析结果

Tab. 4 RDA results of phytoplankton and environmental factors in Hejiang River

\begin{tabular}{|c|c|c|c|c|c|c|c|c|}
\hline \multirow{2}{*}{ 项目 } & \multicolumn{2}{|c|}{ 轴 1} & \multicolumn{2}{|c|}{ 轴 2} & \multicolumn{2}{|c|}{ 轴 3} & \multicolumn{2}{|c|}{ 轴 4} \\
\hline & 丰水期 & 枯水期 & 丰水期 & 枯水期 & 丰水期 & 枯水期 & 丰水期 & 枯水期 \\
\hline 特征值 & 0.241 & 0.317 & 0.196 & 0.222 & 0.162 & 0.120 & 0.121 & 0.086 \\
\hline 物种一环境相关性 & 0.938 & 0.995 & 0.981 & 0.992 & 1.000 & 1.000 & 0.986 & 0.991 \\
\hline 物种一环境累计百分比/\% & 27.9 & 35.9 & 50.7 & 61.0 & 69.4 & 74.6 & 83.5 & 84.3 \\
\hline
\end{tabular}

营养盐是影响浮游藻类分布的一个重要环境因子 ${ }^{[31-32]}$, 本研究中丰水期 $\mathrm{NH}_{3}-\mathrm{N} 、 \mathrm{TP}$ 浓度显著高于枯水 期 (表 2), 原因可能是丰水期雨量大,强降水冲刷土壤中积累的营养盐进人水体,也可能是冲击河底沉积物, 

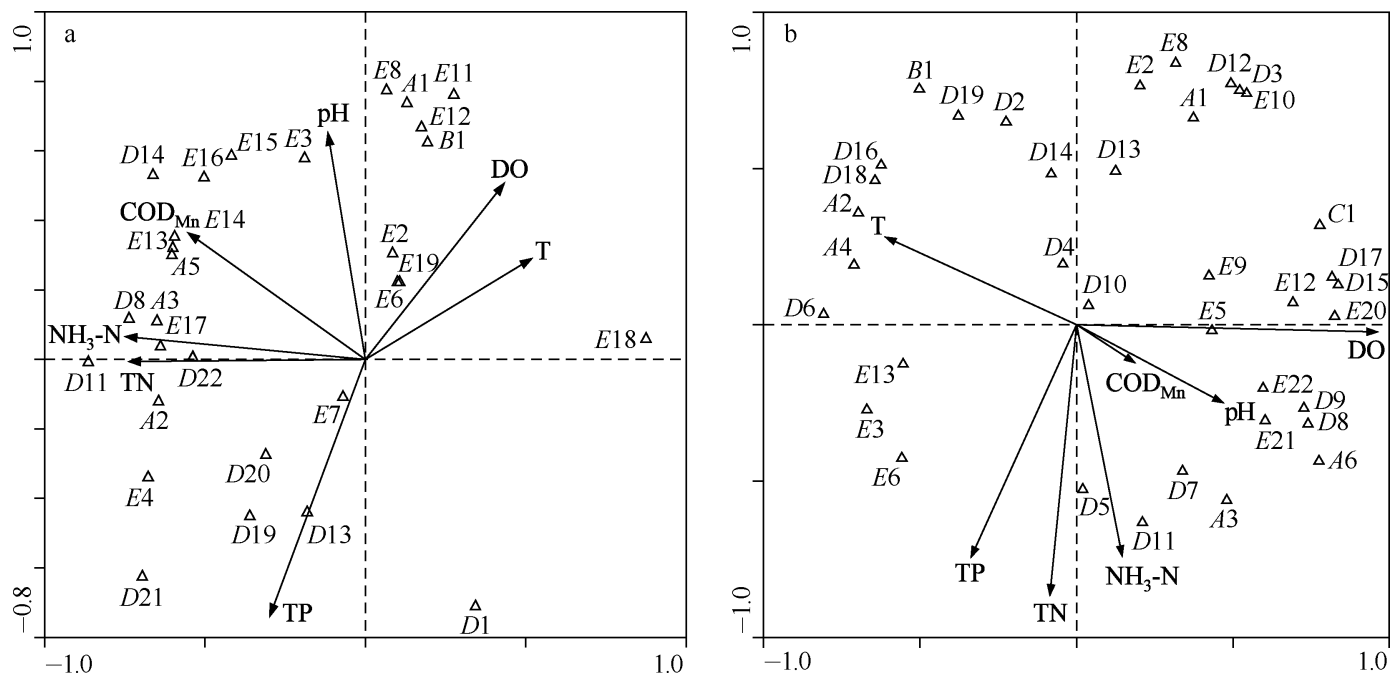

图 4 贺江丰水期 (a) 和枯水期 (b) 环境因子与浮游藻类的 RDA 分析

Fig. 4 RDA results of environmental factors in wet (a) and dry (b) seasons and phytoplankton in Hejiang River

使已经沉积的营养盐再度释放出来, 从而导致营养盐浓度的显著升高. RDA 分析也显示, 水体氮、磷浓度对 贺江浮游藻类分布影响极大. 有研究认为当水体中 TN 和 TP 浓度分别达到 0.2 和 $0.02 \mathrm{mg} / \mathrm{L}$ 时, 就有可能 发生藻类 “水华” 现象 ${ }^{[33]}$. 贺江丰水期和枯水期 TN、TP 平均浓度均远高于藻类水华发生的氮、磷阈值, 并且 含量较高的区域集中在 $2^{\#} \sim 4^{\#}$ 之间, 该河流段穿过居民生活区, 接纳了周围片区的城市生活污水以及农业 生产的面源污染废水, 人为因素导致 TN、TP 浓度偏高. 将贺江及贺江流域主要梯级水库的 TN、TP 浓度与南 方地区其它河流、水库进行比较 (表 5), 结果显示贺江 TN 浓度居于中间水平, 高于西江干流和香溪河库湾, 低于九龙江; TP 浓度处于较低水平, 低于西江干流、九龙江和香溪河库湾. 龟石水库和合面狮水库 $\mathrm{TN}$ 浓度 高于高州水库, 低于东江剑潭水库. 已有研究表明 ${ }^{[34,36]}$, 高州水库和九龙江发生过藻类 “水华” 现象. 河流水 华发生的主要影响因素包括水体中含有丰富的氮磷营养盐、缓慢的水文水动力以及适宜的气象条件 ${ }^{[38]}$, 贺 江流域营养盐已满足藻类水华发生的条件, 并且由于水库的阻隔使贺江部分河段的水体滞留时间较长, 水 体流速相对较缓. 此外, 流域处于亚热带季风气候区, 气候温暖湿润, 为藻类的大量快速繁殖提供了有利的 外部条件. 因此,贺江发生藻类“水华”的风险较高,特别是水库区.

表 5 不同河流(湖库) TN、TP 浓度

Tab. 5 TN and TP concentrations in different rivers and lakes

\begin{tabular}{ccccc}
\hline 类型 & 河流(湖库)名称 & $\mathrm{TN}$ 浓度 $/(\mathrm{mg} / \mathrm{L})$ & $\mathrm{TP}$ 浓度 $/(\mathrm{mg} / \mathrm{L})$ & 数据来源 \\
\hline 河流 & 贺江丰水期 & $1.26 \sim 3.06$ & $0.02 \sim 0.20$ & 本研究 \\
& 贺江枯水期 & $1.22 \sim 2.75$ & $0.02 \sim 0.13$ & 本研究 \\
& 西江干流 & $1.53 \sim 1.63$ & 0.12 & 本研究 \\
九龙江 & $2.50 \sim 8.65$ & $0.09 \sim 1.15$ & 文献 $[34]$ \\
& 香溪河库湾 & $1.060 \sim 1.212$ & $0.145 \sim 0.233$ & 文献 $[35]$ \\
皮库 & 龟石水库 & $1.26 \sim 1.92$ & 0.02 & 本研究 \\
& 合面狮水库 & $1.57 \sim 1.67$ & $0.05 \sim 0.08$ & 本研究 \\
& 高州水库 & $0.600 \sim 1.684$ & $0.010 \sim 0.037$ & 文献 $[36]$ \\
& 东江剑潭水库 & $1.790 \sim 7.780$ & $0.080 \sim 0.330$ & 文献 $[37]$ \\
\hline
\end{tabular}

\section{4 结论}

1) 调查期间共检出浮游藻类 7 门 130 种, 枯水期检出的浮游藻类种类最多, 以硅藻门种类为主, 浮游藻 
类群落为绿藻-硅藻-蓝藻型,藻细胞总丰度在枯水期高于丰水期.

2) 贺江水体整体处于中营养水平, 龟石水库样点的藻细胞丰度较高, 丰水期、枯水期均高达 $10^{7}$ 数量 级,发生藻类水华的潜在风险较高.

3 ) 贺江浮游藻类群落的分布受水体理化性质的影响较大, 氮、磷营养盐是影响贺江浮游藻类群落分布 的关键因素, 控制外源氮、磷的输人,加强流域的生态环境保护、水生态监测和影响因子作用机理研究, 对防 范贺江水体的藻类水华有重要意义.

\section{5 参考文献}

[ 1 ] 卢碧林, 严平川, 田小海等. 洪湖水体藻类藻相特征及其对生境的响应. 生态学报, 2012, 32(3) : 680-689.

[ 2 ] Jiang YJ, He W, Liu WX et al. The seasonal and spatial variations of phytoplankton community and their correlation with environmental factors in a large eutrophic Chinese lake (Lake Chaohu). Ecological Indicators, 2014, 40 : 58-67.

[ 3 ] 谭 香, 夏小玲, 程晓莉等. 丹江口水库浮游植物群落时空动态及其多样性指数. 环境科学, 2011, 32 (10): 2875-2882.

[ 4 ] Cabrita MT. Phytoplankton community indicators of changes associated with dredging in the Tagus estuary (Portugal). Environmental Pollution, 2014, 191: 17-24.

[ 5 ] 韩欢欢, 范亚文. 黑龙江省安兴湿地秋季浮游植物群落结构. 湖泊科学, 2012, 24(4): 577-585.

[ 6 ] Wehr JD, Descy J. Use of phytoplankton in large river management. Journal of Phycology, 1998, 34 (5) : 741-749.

[ 7 ] Reynolds CS, Descy JP. The production, biomass and structure of phytoplankton in large rivers. Large Rivers, 1996,10 $(1 / 2 / 3 / 4): 161-187$

[ 8 ] 江 源, 彭秋志, 廖剑宇等. 浮游藻类与河流生境关系研究进展与展望. 资源科学, 2013, 35(3) : 461-472.

[ 9 ] 王爱爱, 冯 佳, 谢树莲. 汾河中下游浮游藻类群落特征及水质分析. 环境科学, 2014, 35(3) : 915-923.

[10］李芳芳, 童 芳, 段 梦等. 大辽河水系夏季浮游植物群落结构特征及水质评价. 生态学杂志, 2011, 30(11): 2489-2496.

[11］国家环境保护总局《水和废水监测分析方法》编委会. 水和废水监测分析方法:第 4 版. 北京: 中国环境科学出版 社,2002.

[12］胡鸿钧, 魏印心. 中国淡水藻类——系统、分类及生态. 北京: 科学出版社, 2006.

[13] 金相灿，屠清瑛. 湖泊富营养化调查规范: 第 2 版. 北京: 中国环境科学出版社, 1990.

[14] 武 丹, 王海英, 张 震. 天津于桥水库夏季浮游生物调查及群落结构变化. 湖泊科学, 2013, 25(5): 735-742.

[15] Lopes MR, Bicudo CE, Ferragut MC. Short term spatial and temporal variation of phytoplankton in a shallow tropical oligotrophic reservoir, Southeast Brazil. Hydrobiology, 2005, 542 (1) : 235-247.

[16] 邓建明, 蔡永久, 陈宇炜等. 洪湖浮游植物群落结构及其与环境因子的关系. 湖泊科学, 2010, 22(1): 70-78.

[17] Vazquez G, Castillo JA, Favila ME. Algal assemblages and their relationship with water quality in tropical Mexican streams with different land uses. Hydrobiology, 2011, 667(1): 173-189.

[18] Cajo JF. Canonical correspondence analysis: A new eigenvector technique for multivariate direct gradient analysis. Ecolo$g y, 1986,67(5): 1167-1179$.

[19] 祁继英, 阮晓红. 大坝对河流生态系统的环境影响分析. 河海大学学报: 自然科学版, 2005, 33(1): 37-40.

[20] 徐 宁, 段瞬山, 林秋奇等. 广东大中型供水水库的氮污染与富营养化分析. 生态学杂志, 2004, 23(3): 63-67.

[21] 况琪军, 胡征宇, 周广杰. 三峡库区藻类种群结构与丰度变化及其与氮磷浓度的相关性分析. 长江流域资源与环 境, 2007, 16(2): 231-235.

[22] Duarte P, Macedo MF, Dafonseca LC. The relationship between phytoplankton diversity and community function in a coastal lagoon. Marine Biodiversity, 2006, 183 : 3-18.

[23] 刘建康. 高级水生生物学. 北京: 科学出版社, 1999: 176-198.

[24] 江 源, 王 博, 杨浩春等. 东江干流浮游植物群落结构特征及与水质的关系. 生态环境学报, 2011, 20(11)： 1700-1705.

[25] 王 超, 李新辉, 赖子尼等. 珠三角河网浮游植物生物量的时空特征. 生态学报, 2013, 33(18): 5835-5847.

[26] 李思阳, 韩志勇, 许振成等. 高州水库浮游植物群落结构及其与环境因子的关系. 水生态学杂志, 2013, 34(5): 16-23. 
[27] 王 丽, 魏 伟, 周 平等. 铜陵市河流冬季浮游植物群落结构及其与环境因子的关系. 应用生态学报, 2013, 24(1): 243-250.

[28 ] Wang ZH, Cui FY, An Q. Influence of water temperature and trophic value on algae blooming in reservoirs. Ecology and Environment, 2005, 14(1): 10-15.

[29] 刘春光, 金相灿, 孙 凌等. $\mathrm{pH}$ 值对淡水藻类生长和种类变化的影响. 农业环境科学学报, 2005, 24 (2) : 294-298.

[30］聂国朝. 襄阳护城河水体中溶解氧含量研究. 水土保持研究, 2004, 11(1): 60-63.

[31] Lope M, Chan KS, Ciannelli L et al. Effects of environmental conditions on the seasonal distribution of phytoplankton biomass in the North Sea. Limnology and Oceanography, 2009, 54(2) : 512-524.

[32] 邱小踪, 赵红雪, 孙晓雪. 宁夏沙湖浮游植物与水环境因子关系的研究. 环境科学, 2012, 33(7): 2265-2271.

[33] Birch S, McCaskie J. Shallow urban lakes: a challenge for lake management. Hydrobiologia, 1999, 395/396: 365-378.

[34] 边归国, 陈 宁, 胡征宇等. 福建某河流甲藻水华与污染指标的关系. 湖泊科学, 2010, 22(3): 405-410.

[35] 许 涛, 王雨春, 刘德富等. 三峡水库香溪河库湾夏季水华调查. 生态学杂志, 2014, 33(3): 646-652.

[36] 姚玲爱, 赵学敏, 周广杰等. 广东省高州水库春季蓝藻水华成因初步探讨. 湖泊科学, 2011, 23(4): 534-540.

[37] 胡 芳, 许振成, 姚玲爱等. 剑潭水库浮游植物群落特征与水环境因子关系研究. 环境科学学报, 2014, 34(4): 950-958.

[38] 赵学敏, 马千里, 姚玲爱等. 龙江河水体中氮磷水质风险评价. 中国环境科学, 2013, 33(S1) : 233-238. 